\title{
Alienation as foreignization strategy in international and national media discourse in Russia and Germany
}

\author{
M. V. Milovanova \\ Russian Language and Documentation Study Department \\ Volgograd State University \\ Volgograd, Russia \\ mv_milovanova@volsu.ru
}

\author{
M. Yu. Svinkina \\ Russian Language and Documentation Study Department \\ Volgograd State University \\ Volgograd, Russia \\ tipp@volsu.ru
}

\begin{abstract}
This paper focuses on different ways of the "alien" representation in the Russian and German media discourse based on essentials of cultural and discourse linguistics. Most research thus far has focused on the media text rather than on media uses and practices. With references to the political and social contexts, it will be demonstrated how the opposition "ownalien" is effectively used for supporting national consciousness and identity. The "own-alien" polarization has a variable base: on the international level - Russia vs. ideological opposite state; on the national level - authority vs. ordinary folk, locals vs. migrants etc. The analysis of Russian and German press articles over the period from 2013 to 2017 has shown that the most dominating foreignization strategy in the both media discourses is the strategy of alienation. For a more comprehensive research, the study material was broken up into two categories: a national and an international media discourses. As a result, the most popular tactics and communicative turns of the alienation strategy representation were exposed in the both media discourses, as well as the specific character of the "alien" verbalization in different cultures was described. The discourse and contrastive analysis of Russian and German newspaper texts is used as the research method.
\end{abstract}

Keywords-alien; alienation strategy; foreignization; media discourse; media influence.

\section{INTRODUCTION}

In several different ways, the media texts express and reflect the changes in society and people's minds during major societal breaks and crises [1]. Human perception of reality is effected by the particular media which interpret and filter the sense of messages in their own way. Due to the main tasks of media discourse - informing and persuading - mass media might create a concrete image of some occasion and its participants [2]. The language of media has its rules. It is largely built around images, not visual, images in the neuroscientific sense [3]. The representation of social conflicts dividing people into two groups namely "us-them" or "ownalien" is of special interest within this study. The perception of the "other" and man's automatic or deliberate "classification" of people, things and phenomena as "close/familiar" (own) or "distant/alien" (other's), according to their origin, function and/or character, constitute the core of the problem [4]. It is worthy of note that the exclusion of intensity, separation between the own and the alien in the time of globalization and information revolution should in theory disappear. Internet and social networks can bridge the spatial borders among ethnical, gender-based, confessional communities as far as they build up an open common space for personal interaction and cultural exchange, networking and business relationships [5]. In the real life, however, one is bound to acknowledge that the "own-alien"/ "us-them" opposition tends to be one of the most relevant for media to explain the particular antagonism against several personalities or the whole social groups on the base of stereotypes with objective arguments concerning the existence of "different", "other", and "alien" [6].

\section{PRESS FOREIGNIZATION STRATEGIES}

The human mind is extraordinary complex, the way discourse may influence it inevitably involves an intricate process. It can only be managed in real time by applying efficient strategies [7]. Research on the complex interplay between text, context and reception has often been inspired by Stuart Hall's famous work on interpretative frameworks. By bringing semiotics into the study of communication processes, the model suggests that media meanings are produced in social and cultural contexts, which include everything from the broader ideological discourses in a specific society to a person's unique personal histories, experiences and knowledge [8]. Media are mediated and understood through human culture as a social process. Media on the market are received, modified and adopted by the individual's everyday life. The focus is turned to those social processes that shape and transform the relations between various actors and institutions, which socially construct the development, use and the perception of a medium among people.

Identity changes and reconstructions take place in the discursive field. Changing individuals' and groups' perceptions of themselves and others is related to changes in the dominant discourse in society. How people perceive the world around them, which is shaped by the dominant political discourse, determines how they see themselves and each other. 
In the media discourse, the idea of foreignness as the most extreme form of otherness is performed by means of foreignization strategies. It is a kind of strategies which provide a negative (in rare cases neutral) emotional connotative sentiment of a text [9]. Foreignization (from foreignness - the quality of being alien or not native [10]) means the process of distancing and rejecting foreign culture values with highlighting its otherness.

The analysis of Russian and German press articles over the period 2013 to 2017 has shown that the most dominating foreignization strategy in the both media discourses is the strategy of alienation (from Latin alius (signifies different) other, exotic). This strategy is aimed at shaping "alien" image and focusing the reader's attention on "the radical strangeness".

According to the conception introduced by German philosopher and anthropologist Bernhard Waldenfels about two kinds of foreignness (inside and outside the known world), it is possible to distinguish in this research a national (internal) and international (external) media discourses, which allows us to conduct a comprehensive analysis of alienation strategy actualization [11].

\section{ALIENATION STRATEGY IN THE INTERNATIONAL MEDIA DISCOURSE IN RUSSIA AND GERMANY}

Let us use the term "international media discourse" to mean discursive practices representing immediate and mediate contexts which describe interaction between representatives of different linguocultures by nomination of the country, the nationality or realias.

Within the framework of the abovementioned discourse, the alienation strategy results in the use of three tactics: contrasting, threatening and demonizing dealing with human feelings and emotions.

\section{Contrasting tactic}

The contrasting tactic is intended to form the own community and the alien community as an essential opposition. The tactic is implemented in media discourse by means of particular communicative turns.

Awakening interest turn is based on the assumption that "alien" appears unknown, undefined therefore s/he is of information value. This turn is more easily seen in the headlines.

To arouse the interest, journalists turn to interrogative constructions or interrogative words (Сирия - это вообще zde?/ Syria ... where is it in the least?; Was Amerika von uns unterscheidet?/ What does Amerika differ from us?; Was sich russische Kinder von Väterchen Frost wünschen?/ What do the Russian children want to get from Father Frost? ); similes (Ближневосточный менеджмент: Чем турецкий подход к бизнесу отличается от русского?/Middle East management: what does the Turkish approach to business differ from a Russian one?; Sind Deutsche klüger als Türken?/Are Germans smarter than the Turks?); metaphors (Was steckt in der Blackbox Amerika? / What does the blackbox Amerika hide?), jargonisms / slang expressions
(Посмотри, как жсивут правильные английские пацаны!! / Look, how real English guys live), collocations with a lexical item "чужой" / "fremd" (alien) (Чужие проблемы: Зачем России Сирия?/ Alien (someone else's) problems: why Russia needs Syria; Amerikas fremde Werte?/ Alien values of Amerika); transformed precedential texts (Дом, который построил Джек: как изменится английский дизайн до и после Брексита? / The house that Jack built: how will the English design look like before and after the Brexit?; Что Трамn грядущий нам готовит?/ Who knows what Trump tomorrow brings?), proper nouns of cult-favorite characters (Дядя и тетя Сэм: Что нужно знать о Дональде Трампе и Хиллари Клинтон?/ Aunt\& Uncle Sam: what should we know about Donald Trump and Hillary Clinton?)

The question in the headlines above does not possess an interrogative semantic; in fact it facilitates to draw reader's attention to current events happening in other countries by highlighting the difference in behavior of their residents and approaches they choose in comparison with Russians or Germans.

Contrast turn is targeted at making oppositions and distancing from the "alien" by the comparative way with due regard to different criteria.

Foreignness can be expressed by means of direct assertions regarding inappropriateness of difference as it is. The dominating language means are the statements with the predicative "нельзя" (not allowed), negative particle "не" (not), which signifies the radical disagreement: Так жсить нельзя: резиденция Дональда Трампа / It is not allowed to behave in such way: residence of Trump; Нам не понять американской демократии / We won't be able to understand the American democracy. Contrasting context is implemented by a direct comparison or a conjunctionless comparative complex: «Федоров: «Мы не хотим стать такими, как американцы» / Fedorov: "We don't want to be like the Americans; Mы не американцы, толстяков не penpeccupyem / We are not Americans, we do not take the repressive actions against fatties.

In the next example the "own-alien" opposition is presented by the inclusive pronoun "we" and passages with the antonym indicating the "others": «Альфа»: Первые в мире - мы, а не американские ТЮЛЕНИ / Alpha Group: we are the first in the world, not the American LOUTS. The graphical display of the lexical item attracts interest and refers to the U.S. Navy's primary special operations force (Navy SEALs / «Морские котики»). It is worth noting that the choice of this nomination might be explained according to the meaning of the lexical item "seal" which translation corresponds in Russian to «тюлень» (lout) or «морской котик» (seal), i.e. these words are part of a synonymic row. But as for the associative field, the Russian «тюлень» stands for a laggard and dilatory person providing a negative assessment in contradistinction from the Russian «котик» which is normally used in its figurative meaning as a term of endearment, e.g. for a man who one is in love with [12]. This observation gives evidence of association lacuna in the present context. 
The material analysis has shown that in the national media, Russia usually opposes not to the certain country but to some coalition, more specifically to the West, the European Union, Europe.

Western countries are portrayed as Russia's opponents or enemies: «Слуцкий назвал Запад оппонентом России» / Slutsky has qualified the West as an opponent of Russia ; they raise social and economic difficulties and gain to destabilize our country: Евросоюз расииряет санкции против Poccuu / The European Union is extending sanctions against Russia.

The actions of the representatives of other countries are described by the use of emotionally colored vocabulary with the meaning of aggressive physical impact: Сначала Запад попьттался «разорвать в клочья» экономику России, ввёл санкции, затем ударил по спортсменам / First the West tried "to rip to shreds" the Russian economy, introduced sanctions, then hit the athletes. In the German media discourse, the contrast turn is implemented by adversativecomparative constructions.

The contrast turn is used more often in the media discourse of both countries in the articles devoted to the USA. This fact is caused by the highest percentage of references to America in the Russian and German press, firstly, as a state pursuing an active foreign policy, and, secondly, as a country standing out for its cultural background.

\section{Threatening tactic}

"Alien" can be represented as an opponent with contending interests, a rival or an enemy. The threatening tactic is implemented in media discourse by means of communicative turns, such as fear provoking, fomenting a communicative tension and detection of opponent's intension.

The fear provoking turn is aimed at fuel concerns, recalling recipient to a sense of alarm before a real or a fake threat, something unknown.

The most productive means in the both media discourses are metaphors. According to the research work by Zheltuhina M.R. and Magomadova T.D, the modern media discourse is marked by an increasing metaphor role in mass media as an effective expressive means of language [13]. In this study, the most useful ones are metaphors with such source domains as "war" (Дисфункиия Туриии: убийство посла России мина замедленного действия / Disfunction of Turkey: assassination of the Russian ambassador as a delayed-action mine; Putins neue Superwaffe: Russischer HyperschallGleiter „Yu-71“/ New Putin's weapon: hypervelocity glider „Yu-71“/ Russland ist zurück auf der Weltbühne - und angriffslustig / Russia is back and is ready to hit on), "disease" (Сезонная аллергия: разлад России и Украиньл / Seasonal allergy: dissension between Russia and Ukraine; Die Metastasen sind überall / The metastasis are everywhere), as well as occasionalisms (трампономика (Trump + есопоту), Trumpheit (Trump + Dummheit (stupidity)). The occasionalisms provided in the brackets are created in accordance with standard word-building patterns. Two other examples - Stoppt Nazis und „Erdowahn"; Gewehrdogan ist $d a$ - correspond to blend words, the roots which their apply to are proper nouns and are used the connotative words as an intensifier: Erdowahn = Erdogan + Wahnsinn (madness), Gewehrdogan $=$ Gewehr (weapon) + Erdogan .

A chrematonim deconstruction case was also noticed (onomastic vocabulary): Der Cocktail Putin: Aggressor, verletzte Seele, Isolationist / The Putin cocktail: aggressor, of unsound mind, isolationist? In the particular sentence, the word-combination "Der Cocktail Putin" stands for "Molotov Cocktail" also known as a petrol bomb, improvised incendiary weapons.

Metaphors with the source domain "hunt" are registered only in the Russian language: Сети турецкой дружбы / Nets of Turkish friendship; Двойной капкан: Запад заманивает Россию в новую ловушку / Mantrap duplex: the West is luring Russia into a trap; Америка: Ядерная ловушка для России / America is a nuclear trap for Russia.

Fomenting a communicative tension turn is based on creating a divisive atmosphere, spreading negative information and indicating failure of trust.

The language means for implementing this turn are exclamatory constructions in terms of emotional arguments: Россия и Туричя. Как прежде уже не будет! / Russia and Turkey. Things will never go back to the way they were before; Das deutsch-türkisches Verhältnis ist kaputt! / The German-Turkish relations are broken. Word-combinations delivering anxious feeling: große Sorge / big worries; die Lage ist heikel / the situation is shaky; Anspannung ist spürbar / the tension feelable. Lexical items implying for the semantic field "termination", "end": Конец дружбе: Россия отказывается от украинских нефтепроводов / The end of friendship: Russia refuses Ukrainian petrol pipes; Последний раз Петра Порошенко в Крыму / The last time for Petro Poroshenko in Crimea; Адьё, Олланд! Париж нам не нужен / Adieu, Hollande! We don't need Paris anymore.

Detection of opponent's intension turn is primarily intended to expose true colors of a particular opponent, to uncover his/her plans or to explicate the second plane of the content. The following language means are used for the verbal expression of this turn:

- complex sentences with a complement clause, as well as parallel syntactic constructions (делает все, чтобы ... и все это делается для того, чтобы): Синдзо Абэ делает все, чтобы предстать лучиим другом России. Все это, как полагает японская общественность, делается для того, чтобы 15 декабря в ходе визита в Японию Владимир Путин передал Японии четыре острова Курильской гряды (Shinzo Abe is doing everything in his power in order to look as if he was the best friend of Russia. As the Japanese society presumes, all of these is being done so that on the 15th of December in the framework during his visit to Japan Vladimir Putin would pass the Kuril Islands over.)

- appeal to authority: Официальный представитель МИД Мария Захарова уже во второй раз уличила англоязычную редакичю канала Euronews в распространении ложной информации / The spokesperson of the Russian Ministry of Foreign Affairs Maria 
Zakharova has convicted for a second time the Englishspeaking staff of Euronews of lying.

In the German media discourse, a part of "exposer" is usually assigned directly to the news agencies. Most often the German media suggest making a further investigation of the released information and questinable facts.

\section{Demonizing tactic}

The most popular technique within the analysed tactic is stereotypical zoomorphization turn. It is interesting that this tactic is more commonly used in the German media discourse: Russland unter Putin: Bär und Bärenführer / Russia under the leadership of Putin; bear and bearward; Ein russischer Bär ist kein Teddy / A Russian bear is not a Teddy Bear; Russland in Lateinamerika: Der Bär tanzt Samba / Russia in Latin America: the bear is dancing samba. To emphasize the "foreignness" of other country, negative nominations are used referring to the monstrosity of human nature: Die einzige Rettung vor dem Monster Russland ist Wodka / The only one rescue from the Russian monster is vodka; "Ein antidemokratisches Monster": Marine Le Pen will nach Brüssel, um die EU aufzulösen / An anti-democratic monster: Marine Le Pen goes to Brussels to destroy the EU.

\section{ALIENATION STRATEGY IN THE NATIONAL MEDIA DISCOURSE IN RUSSIA AND GERMANY}

The interest in comparative media representation of otherness inside of national discourses is caused by a certain similarity between Russia and Germany as countries with polyethnic populations. Nowadays analysis of the most often discussed media topics of the migration issue should be considered. The migrant and refugee images became an essential part of this study. With the term "national media discourse", let us define a verbal and cogitative activity characterized by intratextual and extratextual factors, which represents different contexts of interaction between representatives of some social groups belonging to one nation or living on the same territory.

\section{Contrasting tactic}

"Aliens" in Russian press generally appear for the riches, oligarchs and representatives of authority. Contrast turn is implemented by personal and possessive pronouns: Наиим олигархам пора прекратить претворять принцип «я живу хорошо, а вы там как хотите / Our oligarchs should stop to put into force the principle "I am living well and don't care how do you there live". Evaluative word combinations with a pejorative connotation for "aliens" and with a positive connotation for "owns": обманывают и зомбируют население (the elected officials deceive the people and zombify the population) / волонтеры и простые граждане помогают бежениам с юго-востока Украины (volunteers and ordinary citizens help the refugees from the south-east Ukraine). Comparative-adversative constructions: Своя рука владыка. Как удаётся богатеть чиновникам, пока народ нищает?(You are the master of your destiny. How do the civil servants manage to grow rich while the average citizens are getting poorer?); zoomorphic metaphors: Чиновники покидают мэрию столищь, как крысы тонущий корабль
(The officials are leaving the Mayor's office like rats leave a sinking ship); antithesis: Нищие чиновники или как жируют жены единороссов? (Beggar civil servants or how their wives roll in clover) etc. In comparison with a mainly negative sentiment of the Russian publications describing life of the riches, wealthy Germans are represented in neutral tones. Such lexical items are usually used for such nomination as die Reichen (the wealthy), die Anderen (the others), die absoluten Spitzen (Big League), die Wohlhabenden (the well-to-do), die Besserverdiener (people who make more money), die Superreichen (the super rich): Das Leben der Anderen: Reich in Berlin / The life of Others: to be rich in Berlin.

"Foreignness" is interpreted as something unknown, different from the common view of life. In Russian media, "foreign" is equal to "hostile". This fact manifests itself as usage of negative emotionally colored lexis and a lot of negative comparisons.

The second communicative turn within a framework of the contrasting tactic is based on negative characteristic detalization and it is implemented by means of a big variety of nominations applied to "they-group" (богачи (the wealthy), дама с Рублевки (a woman from Rublevka) :: обычный труженик (average hard worker), numerals marking money equivalent of the others' well-being (дизайнерская сумочка за 100 тысяч долларов / designer handbag for 100.000 \$, автомобиль из кожи бизона за 88 миллионов рублей / a car covered in bison leather for 88 mil. roubles), comparative and adversative constructions with conjunctions чем, пока (than, while) or with preposition вместо (instead): домашние водоемы у богатых совсем иные, чем у обывателей / the private ponds of the wealthy are other than the ponds of everyman; Пока обычный труженик мечтает поймать золотую рыбку, чтоб та исполнила все его желания, в дома «власть имущих» таких уже завезли / While an ordinary worker dreams to hook a goldfish to fulfill all his wishes, for the riches was it already delivered.

\section{Distancing tactic}

The aim of the tactic is to dissociate oneself from the others who shape an "alien" circle. As for the opposition "own-alien" the personal nominations are of great consequence. In view of this, the variable agential nouns turn is becoming productive and impactful. All animate nominations of humans are noted by the term "agential noun" [14].

The variable agential nouns turn demonstrates a wider variety (structure) in German; the nomination base is made by ethnic and territorial characteristics: Ausländer (foreigners), ausländische Bürger (non-residents), Einwanderer (newcomers), Migranten (migrants), Flüchtlinge (refugees); the following naming units are used as opposition to foreigners: Biodeutsche (biographical Germans), Standard- $u$ Deutsch-Deutsche (standardized Germans), Einheimische (natural-born citizens). For example the noun CopyrightDeutsche alternatively to Passdeutsche refers to natural-born Germans, emphasizing their originality and supremacy under persons who has either immigrated and been naturalized or under new-comer migrants. As a result, many-multinominal 
antonymic rows were found out within the framework of the "ethnic-not ethnic" opposition.

In the Russian language we marked out agential nouns not only with neutral connotation: иностраниы (foreigners), переселенцы (resettles), выходиы из бывшего СССР (immigrants from former USSR), мигранты (migrants), беженць (refugees). But also nouns with negative connotation referring to "aliens": инородиь (of different descent/nation), чужаки (aliens), пришлье (strangers).

In German national media discourse, ethnonyms are generally used to verbalize national affiliation: Asiaten (Asians), Osteuropäer (East Europeans), Mittelmeermenschen (Mediterranean people). In Russian dominate ethnofolizms (obscene words with an ethnic component): азеры (Azeri, offensive), чурки (Churkas), хачики (Khachiks, ethnic slur), чучмеки (Chuchmeks), узкоглазые (slant-eyed) etc. For instance: I am sick of all these churka illegal workers invading my Russia.

The distance making turn is focused on disconnection people and is implemented by indefinite and demonstrative pronouns (какие-то чечень / kind of chechens; эти мигранты / these migrants), expression «так называемый» (so-called) with a disrespect meaning ( $К$ нам являются так называемые гастарбайтеры - им, кстати, платят куда как меньше, чем аборигенам / So-called guest workers come to us, by the way they are paid less than aborigines; Deutschland ist gespalten: Deutsche und sogenannte Gastarbeiter / Germany is divided: Germans and so-called guest workers); stereotyped semantic expressions «Я не такой, как ...» (I'm not like), «Я ни при чем» (I'm beside the point): Wir sind doch nicht am Flüchtlingselend schuld / We are not guilty in poor migrants' conditions. It could be also used macaronicisms: Салам Алейкум-малейкум, школа! Дети мигрантов в системе образования / As-salāmи 'alaykum or peace be upon you), school! Children of migrants in the educational system. For this turn, metaphors standing for separation people from each other are commonly used. For instance, in the media discourses of the both countries metaphors with a source domain "border" were noticed (Медведева оградили от гастарбайтеров / Medvedev was protected against guest workers with barriers; Колючая Венгрия: Осторожно, границы закрываются! / Barbed Hungary: please mind the closing borders; Flüchtlingskrise: heiße Grenze / Refugee crisis: hotspot borders; Migration: Die Grenze im Kopf / Migration like barriers at the head), as well as the metaphor with a source domain "parallel society" is very frequent in the German press (Parallelgeselschaft: Vorurteile gegen Neukölln in Dresden / Parallel society: prejudice against Newcologne in Dresden).

\section{CONCLUSIONS}

In this article, the authors have taken a lingua-cultural approach to analyse discursive manipulation strategies. The authors studied the various Russian and German on-line publications by focusing on the polarized structures of positive representations of the "own" and negative other's representation expressing ideological and political divisions. The alienation strategy could be implemented with the use of a big variety of language and stylistics means. According to the analysis of the international media discourse, the contrasting tactic is leading in the Russian press; the demonizing tactic prevails in German. In the Russian international media discourse, the alienation strategy can be articulated by means of interrogative constructions, a predicative нельзя (not allowed), a negative particle нe (not), transformed precedential texts, occasionalisms, metaphors (source domain "war", "disease", "hunt"). In the German international discourse, antonyms, occasionalisms, word-combinations with the lexical item "fremd", interrogative constructions, and metaphors (source domain "war", "disease") are more often used. The Russian national media discourse is marked by usage of the antonymic row within the framework of the "usthem" opposition, numerals marking money equivalent of the others' well-being, zoomorphic metaphors". The German national media discourse includes antonymic rows within the framework of the "ethnic-not ethnic" opposition, ethnonyms, and agential nouns.

\section{Acknowledgment}

We would like to acknowledge the director of the Institute of Philology and Intercultural Communication, professor N.L. Schamne and the head of Russian Language and Documentation Study Department, professor D.Yu. Ilyin for the opportunity to conduct the research and publish its results.

\section{References}

[1] L.N. Rebrina, "Compositional Tactics of Forming the Negative Image of the Past in Russian Media," Nauchnyj dialog Journal, No 6 (54). pp. 67 79, 2016. (in Russian).

[2] Z.I. Rezanova, K.S. Shilyaev, "Ukraine and Russia in the social conflict: Metaphorical modeling in Russian media discourse," Rusin Journal. Kishinev, No. 4 (42). pp. 217-234, 2015. (in Russian).

[3] A. Davis, Media and politics. Media and society. London: Bloomsbury Academic, 2011, pp. 83-102.

[4] G. Ghazaryan, The Opposition between the "Own" and the "Other" at the Metalinguistic Level of Cross-Cultural Communicative Acts 2014 | Article /Foreign Languages at Higher Education, vol. 1(16), pp. 14-18, 2014.

[5] S.V. Guzenina, "Foreigner as social stereotype: on socio-psychological aspects of other motherland phenomenon, Vestnik TGU, Tambov, No. 7. pp. 262-269, 2012.

[6] I. V. Nam, E.M. Karaegeorgii, A.I. Ermolova, E.V. Nikitina, "The image of labour migrants constructed by the mass media: the case of Tomsk," Siberian Historical Research. Tomsk, No. 1. pp. 166-193, 2017.

[7] A.L. Peeters, L. d'Haenens, "Bridging or bonding? Relationships between integration and media use among ethnic minorities in the Netherlands", Communications: The European Journal of Communication Research. London, 30 (2), pp. 201-2312005.

[8] S. Hall, Encoding/decoding', in S. Hall, D. Hobson, A. Low and P. Willis (eds) Culture, Media, Language. Working papers in Cultural Studies, 1972-79. London: Routledge and Centre for Comtemporary Cultural Studies. University of Birmingham, 1980, pp. 128-138.

[9] M.Yu.Svinkina, "Foreignness as a linguoculturology category," The world of science, culture and education journal, Gorno-Altaisk, No. 2 (57). pp. 339-3412016

[10] Cambridge Dictionary [Electronic resource]. Access mode: http://dictionary.cambridge.org. 
[11] B. Waldenfels, Grundmotive einer Phänomenologie des Fremden. Suhrkamp, Insel, 134 p.

[12] T.F. Efremova, Russian Explanatory Dictionary [Electronic resource]. Access mode: http://efremova-online.ru/slovarefremovoy/tyulen/110808.

[13] M.R., Zheltuhina, T.D. Magomadova, Military metaphor as means of modern media knowledge communication. In: International Symposium
«Metaphor as Means of Knowledge Communication»: book of abstracts. Perm, 2016. pp. 120-121.

[14] Z.I. Mineeva, "Identification of a person in today's Russian media," Vestnik of Lobachevsky State University of Nizhni Novgorod. Nizhni Novgorod, No. 2-2. pp. 473-477, 2015. 